\title{
COOPERATIVE LEARNING AS A DEMOCRATIC AWARENESS METHOD IN VALUE EDUCATION
}

\author{
Natia Vacheishvili \\ Ilia State University, Tbilisi, Georgia
}

\begin{abstract}
School promotes the moral-cognitive development of the individual and creates the democratic competence of society as a whole. Cooperative learning is a technique for teaching democratic processes through direct experiences. One of the main aims of the comprehensive educational reform in Georgia is to contribute to the democratic development of the country and its future for European integration. The National Plan of Public Schools stated new concepts to moderate educational standards. In various countries cooperative learning has become a widely used instructional procedure in all subject areas. There has never been a research of the effectiveness of cooperative learning at schools in Georgia. This research explores the role of cooperative learning for awareness of democratic values such as self-esteem, responsibility and interdependence. 551 eighth grade students from 16 different classrooms participated in the research. The classrooms were selected randomly as the experimental group and the control group. In the experimental group cooperative learning was employed, while in the control group traditional lecture-based teaching. The subjects were chosen randomly, Chemistry and Georgian language. The experiment was completed within a three term period. For conducting survey there were used some instruments for each variable: Rosenberg's Self-Esteem Questionnaire and Janis-Field Feeling of Inadequacy scale; The Intellectual Achievement Responsibility (IAR) Questionnaire; Relational-Interdependent Self-Construal (RISC) Test; The Scientific Attitude (SAI) Inventory. As an experiment shows, results vary significantly between cooperative learning and traditional group. Results demonstrated that cooperative learning increased students' performance in both subjects and students scored significantly higher on all variables such as self-esteem, responsibility and interdependence, hence cooperative learning has a positive effect on value teaching.
\end{abstract}

Key words: social interdependence theory, cooperative learning, self-esteem, responsibility.

\section{Introduction}

Nowadays, democracy redefines not just the status of the citizen. Globalization and technological developments challenge the process of individualization. From new requirements and understanding of values, arises the demand for modern teaching methods in education. The definition of the three forms of democracy is: 1) a form of living; 2) a form of society; 3 ) a form of government or governance. Democratic teaching involves all these three aspects. In early times, the focus was put on democracy as a form of governance, but today democracy is more than only governance. When we say political-educational, we understand these two terms are inseparable.

Every educational intervention mobilizes political aspects, and every political intervention in school should include democratic educational aspects. Seen in wider context of democratization, two crucial factors influencing the participation of pupils in schools are a society's historical experience and its political environment. 
To increase democratization in all areas and on all levels of society, the transformation of schools into a democratic institution, the stage is set for the increased participation of pupils in the everyday life of the school, not only in learning and teaching. Along with the family, the school is the most important factor for the creation, formation and education of the "informed, responsible, participative citizen". In this context, the school has four educational objectives:

- $\quad$ To empower pupils and students for their future role as citizens;

- $\quad$ To provide opportunities for democratic learning;

- $\quad$ To open up suitable areas or fields for active participation and co-responsibility in the school environment;

- To encourage pupils to actively participate in social life in the larger community and to exercise their rights.

The USA and Europe's leading states pass on a long tradition of a systematic development of democratic consciousness. The opposite situation exists in post-soviet countries (East and South-East Europe), where democracy, as a form of inclusive governance has only been extant for twenty years. Georgia and European states, independently from each other, have followed different ways of democratic educational system formation, and naturally, their identities differ from each other, both, genealogically and typologically; therefore the situation in Georgia is unique. There is emphasized the role of democratic values In the National Plan of Public Schools of Georgia; The school should pay attention to the development of values such as dignity, respect, fairness and recognition of others opinion. It is very important that the teacher shows a personal example of justice and mutual respect to students. Therefore, the "General Educational Law" and "National Educational Goals" directly require from any school to promote and teach fundamental values to students (General Educational Law; 2005, Tbilisi, Georgia; National Educational Goals; 2004, Tbilisi, Georgia).

\section{Social Interdependence Theory and Values in Cooperative Learning}

Learning democratic abilities and skills in school is very important to developinteraction as a valuable source. It is possible to improve academic results with interaction. Teamwork principles are accessible and simple towards a common goal. Social Interdependence exists when the outcomes of individuals are affected by each other's actions (Johnson\&Johnson; 1989). According to Lewin $(1935,1948)$, group members make interdependence through common goals. For interdependence to exist there must be more than one person or entity involved and the people or entities must impact each other, in that change in the state of one causes a change in the state of the others. This impact occurs in the immediate situation, as each person's behavior is determined by how the situation is perceived, rather than by objective or historical factors. It is called the principle of contemporaneity.

Without social interdependence, most students will see themselves in competition with other students for good grades. With positive interdependence, most students work to help others succeed. However, as students work together, there may be opportunities in which students see the potential for success by riding on the efforts of others. Therefore, social interdependence alone is insufficient for effective cooperative learning activities. High self-esteem is also required as well as high responsibility. 
Positive Interdependence is posited to create responsibility forces that increase group members' feelings of responsibility and self-esteem for a) completing their share of the work and b) facilitating the work of other group members (Deusch; 1949, 1962). When people's performance affects the outcomes of collaborators, they feel responsible for their collaborators' welfare as well as one self, is worse. The shared responsibility created by positive interdependence adds the concept of ought to group members' motivation - one ought to do one's part, pull one's weight, contribute, and satisfy peer norms (Johnson; Johnson, 1989). Such feelings of responsibility increase a person's motivation to perform well.

Responsibility forces increase when there is group and individual accountability. Individual accountability exists when the overall performance of the group is assessed and the results are given to all group members to compare with a standard of performance.

Self-esteem is a widely used concept of psychology. It refers to an individual's sense of his or her value or worth, or the extent to which a person values, approves of, appreciates, prizes, or likes him or herself (Blascovich \&Tomaka; 1991). The most broad and frequently cited definition of self-esteem is Rosenberg (1965), who describes it as a favorable or unfavorable attitude towards the self. Self-esteem is generally considered as an evaluative component of self-concept that includes cognitive and behavioral aspects as well as evaluative or affective ones (Blascovich\&Tomaka; 1991).

\section{The Aim of Research}

The aim of the research was to explore the effects of cooperative learning on students awareness involving the value - based education. The intention of this research was to establish a relationship between student self-esteem, interdependence, responsibility and learning techniques. In order to test this relationship, the following hypotheses were formulated:

- Students in the cooperative learning classes will score higher on selfesteem measurements than do students who have been in traditional lecture techniques.

- $\quad$ Students who participate in groups will have more positive interdependence and higher responsibility than those in traditionally taught classes.

- Cooperative learning activities will have a positive effect on the subjects which will be taught by group working.

\section{Methodology of Research}

\section{General Background of Research}

For conducting research on value-based education many instruments have been developed. Among them is self-esteem inventory, Rosenberg's (1965) Self-Esteem Questionnaire and Janis-field feeling of inadequacy scale. They have been widely used in self-esteem researches and found to be a reliable instrument (e.g.ToddF.Heatherton; J.Polivy 1991; John P.Robinson, Philip R.Shaver; Lawrence S.Wrightsman 1995; etc). The RSE and JFS dominated the field and the end of 2000s they were used in 30 per cent of published 
studies (Todd F. Heatherton and Carrie L.Wyland, 2005). For developing the responsibility inventory, researcher used The Crandall Intellectual Achievement Responsibility (IAR) Questionnaire (1965). The Crandall scale is more closely related to attainment than to intelligence, indicating that high internalized reinforcement responsibility provides a motivation for attainment relatively independent of intelligence (Ivan Reid; Audrey Croucher; 1980). Relational-Interdependent Self-Construal (RISC) test (Cross; 2000) was used to measure interdependence. The RISC shows convergent validity with measures of agreeableness, empathy, and communal orientation. Interpersonally, the RISC predicts viewing relationships as close, and committed, weighing how others will experience personal decisions, and being self-disclosing (Cross 2000; Cross \&Morris, 2003; Gore, Cross\&Morris, 2006). The fourth variable in research was the Attitude toward the Subject. The subjects were chosen by random selection, Chemistry and Georgian Language. The Scientific Attitude Inventory (SAI) was used to conduct the research. It has been used extensively throughout the world since 1970 and it continues to be used. Nagy (1978) investigated the SAI "to look for empirical support for the distinction between "feelings" and "beliefs" in a scientific attitude scale" (p.355).

\section{Sample Selection}

The participants were 551 students (452 from experimental group and 91 from control group) 320 girls and 231 boys from eighth grade in secondary schools of Tbilisi (4 local schools were randomly chosen; 3 were state schools and 1 was private). There were 13 classes for experimental group and 3 classes for control group. Each state school class included 35 to-40 students, and 51 students were enrolled in 2 private school classes. In the Chemistry experiment, research looked at teaching, participated one state school with 190 students (from 5 classes), with 154 students in the experimental and 36 in the control group. 262 students from 9 classes participated in the experimental group for Georgian Language with another 55 students from 2 classes in the control group. The research was conducted for 3 terms of 2010-2012. The average age of the participants was 13 years.

\section{Instrument and Procedures}

A combination of quantitative and qualitative research methods were used for research. Individual interviews with students preceded the quantitative research. The research questions were identified and relevant research instruments were selected. The final research tool consisted of four various instruments: Rosenberg's (1965) Self-Esteem Questionnaire with combination Janis-field feeling of inadequacy scale, The Crandall Intellectual Achievement Responsibility (IAR) Questionnaire (1965), Relational-Interdependent SelfConstrual (RISC) test (Cross; 2000) and The Scientific Attitude Inventory( SAI) .

The results were summarized by this way - scoring for Self-Esteem: Law 20-60; Normal 61-75; High 76- 100. The scoring for Responsibility questionnaire: Law 20-60; Neutral 61-75; High 76-100. For interdependence: Low 20-50; Neutral 51-60; High 61-100. Attitude Toward the Subject: (Georgian and Chemistry) the scoring for the scale was Low 2050; Neutral 51-60; High 61-100. Each variable inventory included 20 items. Answers to the questionnaires were rated on a five-point Likert scale measuring aspects of each inventory. 
It was a Likert-type, five point scale in which scores ranged from a minimum of 20 to a maximum of 100 . Participants were asked to rate whether they strongly agreed, agreed, find hard to answer, disagreed or strongly disagreed with 80 statements that examined cognitive, emotional and behavioral choices. $(1=$ strongly agree; $5=$ strongly disagree)

The research lasted for 3 terms ( 1.5 year). While the experimental groups received cooperative learning instruction for their class in subject chemistry or Georgian language and literature, the control groups were taught in the traditional lecture format. In cooperative learning conditions, classes started with subject teachers presenting the lesson material and method. The classes were divided into 4 or 5 student groups in which they continued to work during 3 terms. Each group had chosen a leader of group. The both subjects, Chemistry and Georgian Language and Literature were taught by the methods of cooperative learning. The teachers of these subjects participated in group discussion, answered the students' questions and observed the group work in progress. At the end of each lesson, the spokesperson from each group presented what they had studied with 10 min. presentation.

On the other hand, the students in traditional lecture classes received a traditional lecture which was given by the teacher of subjects (the same subjects, Chemistry and Georgian). In these classes, students usually sat alone in their chairs, did not interact with each other and mostly listened to what teacher was teaching during the lesson. The same method was used in the lab of chemistry lesson. In the period of lab teaching, students followed a guide book and discussed the material individually or in a group. Both classes (experimental and control) were instructed using the same books, study guides, slides and other handout materials. Both sections took the same tests.

In class teaching and lab section there were subjects taught in groups or pairs. Every class included some kinds of class activities in which students used cooperative learning methods. Students were strongly encouraged to learn together and spend more time than usual together. In the control group, as we said, the traditional lecture-based teaching method was used. In these groups, the emphasis was on individual work and the teacher used the lecture method of teaching. In lab sections students were instructed to work on their own, avoid interaction with other students, work hard on the task, complete tasks to the best of their ability and work quietly so that other students would not be disturbed or interrupted. Students were to ask only the teacher for help and check their performance only with the teacher. The teacher, in turn, would praise or reward only competitive and successful students.

\section{Data Analysis}

Various methods were utilized to analyze the data. Frequency analysis, inventory survey and index computation were made on all research. The researcher utilized Statistical Package for the Social Sciences (SPSS) 22 and STATA -12 programs to aid in data analysis. This software provided valuable quantitative information in the form of frequency distribution and percentage. 


\section{Results of Research}

Initially, extensive data of the wave 1 , wave 2 was undertaken to compare the differences of variables. It is observed that at the beginning of the experiment, the students in cooperative learning groups and in traditionally taught groups were very similar before any teaching and learning manipulation was made on them. The tables are shown with the results of survey.

\section{Table 1. Results of the survey.}

Control Group

\begin{tabular}{|c|c|c|c|}
\hline Chemistry & Low & 60.4 & 44.4 \\
\hline Chemistry & Neutral & 28.7 & 27.8 \\
\hline \multirow[t]{2}{*}{ Chemistry } & High & 10.9 & 27.8 \\
\hline & & Wave1 & Wave2 \\
\hline Georgian & Low & 90.3 & 36.4 \\
\hline Georgian & Neutral & 4.8 & 29.1 \\
\hline \multirow[t]{2}{*}{ Georgian } & High & 4.9 & 34.6 \\
\hline & & Wave1 & Wave2 \\
\hline Interdependence & Low & 60.4 & 31.9 \\
\hline Interdependence & Neutral & 28.7 & 33.0 \\
\hline \multirow[t]{2}{*}{ Interdependence } & High & 10.9 & 35.2 \\
\hline & & Wave1 & Wave2 \\
\hline Responsibility & Low & 85.1 & 65.9 \\
\hline Responsibility & Neutral & 12.3 & 26.4 \\
\hline \multirow[t]{2}{*}{ Responsibility } & High & 2.6 & 7.7 \\
\hline & & Wave1 & Wave2 \\
\hline Self-Esteem & Low & 85.1 & 59.3 \\
\hline Self-Esteem & Normal & 11.2 & 37.4 \\
\hline \multirow[t]{2}{*}{ Self-Esteem } & High & 3.7 & 3.3 \\
\hline & & Wave1 & Wave2 \\
\hline Rosenberg & Low & 97.1 & 96.7 \\
\hline Rosenberg & Normal & 2.9 & 3.3 \\
\hline
\end{tabular}

Experimental Group

\begin{tabular}{|l|l|l|l|}
\hline Chemistry & Low & 63.7 & 2.1 \\
\hline Chemistry & Neutral & 25.3 & 9.5 \\
\hline
\end{tabular}




\begin{tabular}{|l|l|c|c|}
\hline Chemistry & High & 11.1 & 88.4 \\
\hline Georgian & & Wave 1 & Wave 2 \\
\hline Georgian & Low & 92.8 & 23.2 \\
\hline Georgian & Neutral & 5.7 & 3.8 \\
\hline & High & 1.5 & 73.0 \\
\hline Interdependence & & Wave 1 & Wave 2 \\
\hline Interdependence & Low & 67.0 & 15.2 \\
\hline Interdependence & Neutral & 25.2 & 6.6 \\
\hline & High & 7.7 & 78.2 \\
\hline Responsibility & & Wave1 & Wave 2 \\
\hline Responsibility & Low & 88.7 & 42.0 \\
\hline Responsibility & Neutral & 10.4 & 38.6 \\
\hline & High & 0.9 & Wave 2 \\
\hline Self Esteem & & Wave 1 & 44.4 \\
\hline Self Esteem & Low & 88.7 & 19.2 \\
\hline Self Esteem & Normal & 10.8 & 65.2 \\
\hline & High & 0.4 & 34.8 \\
\hline Rosenberg & & Wave 1 & Wave 2 \\
\hline Rosenberg & Low & 97.6 & 2.4 \\
\hline
\end{tabular}

According to table 1, the scoring of each variable is different before and after experiment. Before experiment (wave 1) the results were for Self-Esteem: Low- 88.7; Normal -10.8; High- 0. 4. After experiment (wave 2) results changed Low-36.6; Normal44.4; High-19. 2. For control group scoring for wave 1 was: Low-85.1; Normal-11.2; High3.7. Control group Wave 2: Low-59.3; Normal-37.4; High- 3.3. Students in the cooperative learning classes scored significantly higher on self-esteem measurements than did students who were in a traditional lecture techniques.

The results for responsibility indicated the presence of statistically very significant differences between wave 1 and wave 2, as well as difference between experimental and control group results. The results for experimental group in wave 1 were: Low-88.7; Neutral-10. 4; High-0.9.The same group results after experiment changed: Low-19.0; Neutral-42.4; High-38.6. For responsibility control group results were in wave: Low-85.1; Neutral-12.3; High-2.6. In wave 2 the same group results were: Low-65.9; Neutral-26.4; High-7.7.

Compared to students learning by traditional method, students in the experimental group demonstrated more positive attitudes toward the subjects which were taught by cooperative learning method. Results for attitude toward the subjects for experimental group in wave 1 were: chemistry Low-63.7; Neutral-25.3; High-11.1; For Georgian Language: Low-92.8; Neutral-5.7; High-1.5. The results changed in wave 2: chemistry: Low-2.1; Neutral-9.5; High-88.4. Georgian language: Low-23.2; Neutral-3.8; High-73.0. For control 
group in wave 1results were: chemistry Low-60.4; Neutral-28.7; High-10.9. Georgian language: Low-90.3; Neutral-4.8; High-4.9. In wave 2 there were some changes: chemistry Low-44.4; Neutral-27.8; High-27.8. Georgian: Low-36.4; Neutral-29.1; High-34.6.

Interdependence results were for experimental group in wave 1: Low-67.0; Neutral-25.2; High-7.7. The results changed in wave 2: Low-15.2; Neautral-6.6; High78.2. For control group results were in wave 1: Low-60.4; Neutral-28.7; High-10.9. The same group results in wave 2: Low-31.9; Neutral-33.0; High-35.2. The results indicated differences between experimental and control groups.

Table 2. Descriptive statistics results.

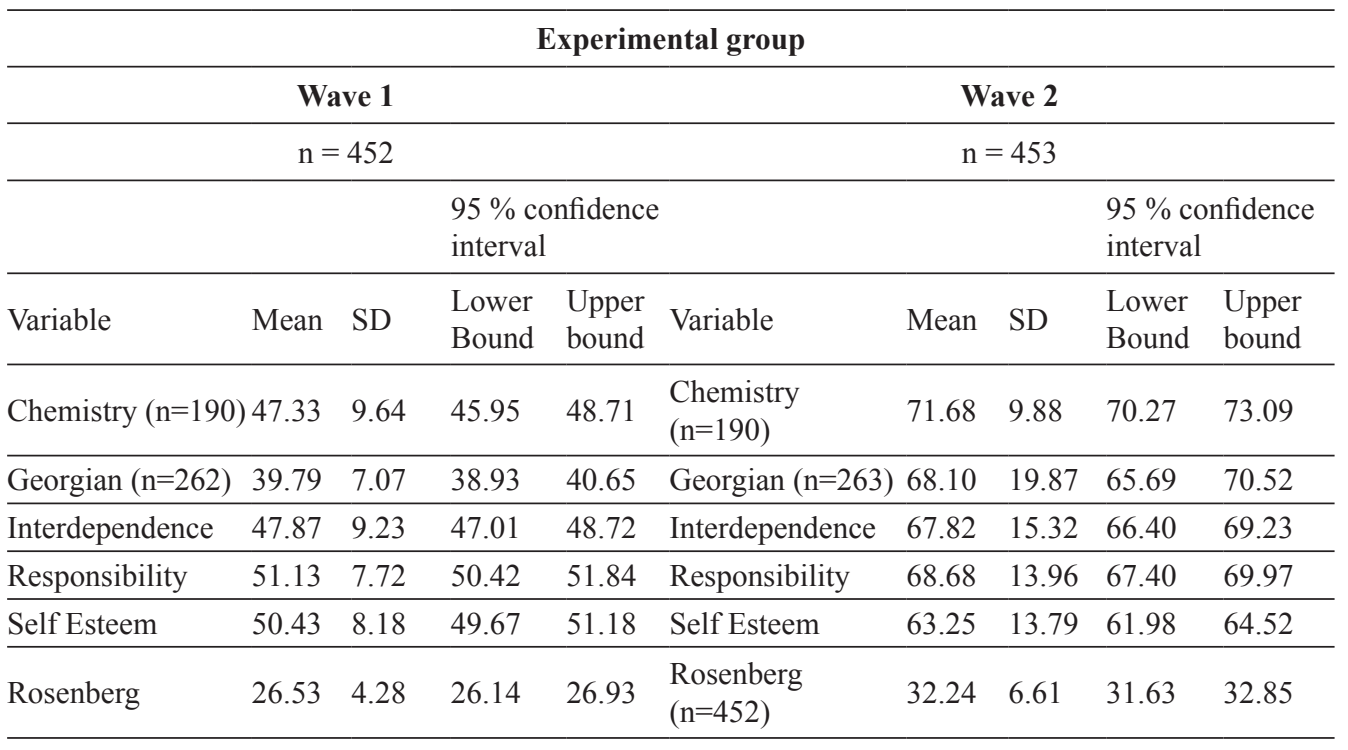

Control group

\begin{tabular}{|c|c|c|c|c|c|c|c|c|c|}
\hline \multicolumn{5}{|c|}{ Wave 1} & \multicolumn{5}{|c|}{ Wave 2} \\
\hline \multicolumn{5}{|c|}{$\mathrm{n}=91$} & \multicolumn{5}{|c|}{$\mathrm{n}=91$} \\
\hline & & & \multicolumn{2}{|c|}{$\begin{array}{l}95 \% \text { confidence } \\
\text { interval }\end{array}$} & & & & \multicolumn{2}{|c|}{$\begin{array}{l}95 \% \text { confidence } \\
\text { interval }\end{array}$} \\
\hline Variable & Mean & SD & $\begin{array}{l}\text { Lower } \\
\text { Bound }\end{array}$ & $\begin{array}{l}\text { Upper } \\
\text { bound }\end{array}$ & Variable & Mean & $\mathrm{SD}$ & $\begin{array}{l}\text { Lower } \\
\text { Bound }\end{array}$ & $\begin{array}{l}\text { Upper } \\
\text { Bound }\end{array}$ \\
\hline Chemistry $(n=36)$ & 46.33 & 9.69 & 47.77 & 50.88 & Chemistry $(n=36)$ & 54.67 & 12.04 & 50.59 & 58.74 \\
\hline Georgian $(n=55)$ & 41.77 & 8.07 & 40.91 & 43.65 & Georgian $(n=55)$ & 56.27 & 11.92 & 53.05 & 59.50 \\
\hline Interdependence & 51.87 & 11.23 & 49.41 & 55.78 & Interdependence & 57.92 & 12.71 & 55.28 & 60.57 \\
\hline Responsibility & 55.13 & 7.72 & 52.42 & 56.84 & Responsibility & 57.47 & 10.20 & 55.35 & 59.60 \\
\hline Self Esteem & 54.43 & 9.18 & 51.67 & 54.18 & Self Esteem & 57.26 & 10.04 & 55.17 & 59.36 \\
\hline Rosenberg & 27.03 & 4.28 & 26.14 & 27.83 & Rosenberg & 28.08 & 4.78 & 27.08 & 29.07 \\
\hline
\end{tabular}


Descriptive statistics demonstrate that students in cooperative learning classes had higher deep learning approach scores than students with traditional learning styles. Mean for self-esteem is 63.25 vs 57.26 . Hypothesis $1^{\text {st }}$ was well confirmed: students in the cooperative learning classes scored significantly higher on self-esteem measurements than did students who were in a traditional lecture environment.

Hypothesis $2^{\text {nd }}$ was also confirmed. Students in experimental group did differ significantly from control group in the responsibility and interdependence variables. The students in cooperative learning groups scored better than in traditionally lectured group. Means for responsibility is $68.68>57.47$; for interdependence $67.82>57.92$.

This research was an attempt to investigate the effects of cooperative learning techniques on students' values and attitudes toward the subject learning (Chemistry and Georgian language). Findings from the analysis of the data gathered by researcher were obtained. In descriptive statistical analysis means are in the following way Chemistry 71.68 $>54.67$; Georgian Language $68.10>56.27$. The hypothesis $3^{\text {rd }}$ was confirmed as well as other ones. Students in experimental group, who were taught using group working method, had more positive attitude toward the subjects than students who were taught by lecturebased method.

During the experiment researcher observed a significantly bigger increases in students' variable level scores with cooperative learning style. This observation can be explained by greater suitability of the teamwork approach used during the experiment. Further effectiveness of the experiment could be explained in the longer term as many researches have described that cooperative learning models worked successfully for a long term course (Kreke, 1998; Shindler, 2004; Sonnenwald\&Li, 2003).

\section{Discussion}

The current research provided strong support for the benefits and effectiveness of cooperative learning methods, which rise students' democratic values. First, the students in this experiment who experienced the cooperative learning groups reported that they found it very useful and beneficial as an instructional method. Students' attitudes and skills towards values as measured with scales revealed that they developed more positive attitude for group work during the whole experiment. This research shows the similar results to that of Brewer \&Klein (2006) in which they found positive interdependence toward group working. It was also qualitatively observed that students in experimental group had more favorable attitudes towards learning material than other students. The research also indicated that cooperative learning tends to promote greater efforts to achieve more positive relationships than do competitive or individualistic efforts. In cooperative efforts, a sense of responsibility to do one's fair share of work presumably motivates actions to achieve the joint goals. Many researchers investigated the same interaction between responsibility and group working. Miller and Hamblin (1963) reviewed 24 studies on cooperation and competition and concluded that cooperative learning can increase students' responsibility. As research results show, before the experiment both groups, experimental and control, had low responsibility levels. After the experiment the share of high scoring grew in the treatment group, while in control group it changed insignificantly. Shaw\&Tremble (1971), Mullen (1983), Norvell\&Forsyth (1984) and Rantilla (2000) reported that cooperative work increases the feeling of responsibility among group members. 
Additionally, in the present research, students in the cooperative learning section enthusiastically attended classes and lab section. In qualitative research, we also found that students interviewing records were better for cooperative group. When control group and experimental group records were compared, it was observed that participation in group working activities naturally encouraged the students to regularly come to the class. Jenkins, Antil and Wayne (2003) mentioned better classroom success rates and academic achievement as a result of cooperative groups.

The present research contributed to an understanding of how group working method could be used effectively for teaching of any (technical, humanitarian) subjects. As the survey results show, the attitude toward the subject changed positively. The benefit from cooperative learning is more compared to traditional lecture method which is teachercentered and does not require independent thinking and effort from the students. Students in cooperative groups develop a higher level of reasoning, easy generation of new ideas and solutions, increased creativity and better transfer of what they learned in one subject to another (Huss, 2006).

One important result of this research is that participation in group works was shown to have a positive effect on students' self-esteem. The present research revealed that more than half of the students had low self-esteem according to Rosenberg's Self-Esteem Scale and there was difference after experiment between experimental and control groups (Kilic, 2008). Similar results were also reported by other researchers (Huss, 2006). However, in a previous research, Ghazi (2003) reported that cooperative learning did not contribute to the student's academic self-esteem and alienation from school. In fact, the relationship between self-esteem and academic success is a complex issue and it is not a unidimensional phenomenon. As Quanwu (1994) reported, cooperative learning causes a positive change in students interpersonal relations and higher self-esteem which leads to more positive attitudes toward life, causes less depressive feelings and anxiety and finally contributes to higher academic achievement.

\section{Conclusions}

The results of current research have shown that cooperative learning promotes positive interdependence among students, grows self-esteem, helps students to obtain a deeper understanding, makes students responsible for the success of each individual in the group, and enhances students' social skills. According to research, group working is an ideal technique for teaching democratic processes through direct experiences. Implementing cooperative learning requires students to make decisions, participate socially and act on values such as turn-taking, sharing and respecting others' point of view. In fact, group working was found to be more effective than lecture-based teaching of the eighth grade students in chemistry and Georgian language. The ability to work with others within a group and to develop interpersonal skills might be additional benefits of using cooperative learning strategies. There are some tips developed from the results of the research:

- $\quad$ Considering the positive contributions of cooperative learning to student development, it makes sense to use group working strategies more often in any subject teaching. According to qualitative survey results, active learning and cooperative learning methods in curriculum are not sufficiently used. 
- It is revealed in the research that cooperative learning is more effective than lecture-based teaching. Teachers should be given opportunities to use cooperative learning activities in particular. They might also learn how to design cooperative learning activities in classrooms.

- $\quad$ Forthcoming research might also focus on teacher's role in implementing cooperative learning in the class room, how to use cooperative learning pedagogy to facilitate thinking and learning among students across different educational settings.

\section{References}

Blasovich, J., Tomaka, J. (1991). Measures of self-Esteem. Measures of Personality and Social Psychological Attitudes, 2, 115-160.

Brewer, S., Klein, J. (2006). Type of positive interdependence and affiliation motive in an asynchronous, collaborative learning environment. Educational Technology Research and Development, 54 (4), 331-354.

Bulut, S. (2009). The effect of cooperative learning techniques on pre-service teachers, selfesteem, achievement and absences. Suvremena Psihologia / Contemporary Psychology, $12,23-41$.

European Commission, Directorate General for Education and Culture, 2015. Europe 2020 Strategy. Retrieved from http://www.europa.eu.int/comm/dgs/education-culture/indexen.htm

Flemin, J. S., Courtney, B. E. (1984). The dimensionality of self-esteem: Hierarchical facet model for revised measurement scales. Journal of Personality and Social Psychology, 46, 404-421.

Forsyth, D., Kelly, K. (1994). Attribution in groups, estimations of personal contributions to collective endeavors. Small Group Research, 25, 367-383.

Georgian National Educational Law (2005). Retrieved from http://www.mes.gov.ge.

Higgs, G. F. (1995). Rethinking locus of agency in the at-risk condition; Retrieved from http:// files.eric.ed.gov/fulltext/ED394110.pdf.

Huss, J. A. (2006). Gifted education and cooperative learning: A miss or a match? Gifted Child Today, 29, 19-23.

Johnson, D. W., Johnson, R. T. (1989). Cooperation and competition: Theory and research. Edina, MN: International Book Company.

Johnson, D. W., Johnson, R. T. (1990). Social skills for successful group work. Educational Leadership, 7, 29-33.

Johnson, D. W., Johnson, R. T. (2005). New developments in social interdependence theory. Social and General Psychology Monographs, 131 (4), 285-358.

Kreke, K., Fields, A., Towns, M. H (1998). An action research project on student perspectives on small-group activities in chemistry: Understanding the efficacy of small-group activities. Paper presented at the annual meeting of the National Association for Research in Science Teaching; San Diego, CA.

Leary, M. R. (1999). Making sense of self-esteem. Current Directions in Psychological Science, $8,32-35$.

Leming, J. (1993). Synthesis of research: In search of effective character education. Educational Leadership, 51 (3) 63-71. 
Lewin, K. (2007). Psychology. Lewin Press.

Lickona, T. (1993). The return of character education. Educational Leadership, 51 (3), 6-11.

McClellan, B. (1992). Schools and shaping of character: Moral education in America. Social Science Education and the Studies Development Center, Indiana University, 8, 130-135.

Miller, L. K., Robert, L. (1963). Interdependence, differential rewarding, and productivity. American Sociological Review, 28 (5), 768-778.

Mullen, B. (1983). Self-attention theory: The effects of group composition on the individual. Theories of group behavior. Springer Series in Social Psychology, 10, 125-146.

National Educational Goals (2004). Retrieved from http://mes.gov.ge/index.php?lang=eng.

Quanwu, Z. (1994). An intervention model of constructive conflict resolution and cooperative learning. Journal of Social Issues, 50 (1), 99-116.

Rantilla, A. K., Budescu, D. V. (1989). Aggregation of expert opinions. Retrieving from https:// www.computer.org/csdl/proceedings/hicss/1999/0001/01/00011058.pdf.

Slavin, E. R. (1983). Cooperative learning. Longman, NY: Longman.

Slavin, R. (1990). Cooperative learning: Theory, research and practice. Engelwood Cliffs, NJ: Prentice Hall.

Smith, K. A. (2004). Teamwork and project management. New York; McGraw-Hill.

Wentzel, K. R. (1998). Social relationships and motivation in middle school: The role of parents, teachers, and peers. Journal of Educational Psychology, 90 (2), 202-209.

Received 15 October 2015; accepted 28 October 2015

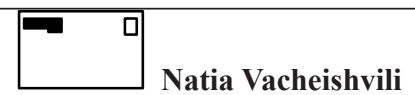

Ph.D Student, Lecturer, Ilia State University, 3/5Cholokashvili Ave., Tbilisi 0162, Georgia.

E-mail: natia_vacheishvili@iliauni.edu.ge

Website: http://www.iliauni.edu.ge 